\title{
ETHNOMATEMATICS THREE PEDAGOGICAL PROPOSALS FOR BASIC EDUCATIONi
}

\author{
ETNOMATEMÁTICA \\ TRÊS PROPOSTAS PEDAGÓGICAS PARA A EDUCAÇÃO BÁSICA

\begin{abstract}
ETNOMATEMÁTICAS
TRES PROPUESTAS PEDAGÓGICAS PARA LA EDUCACIÓN BÁSICA
\end{abstract}

Francisco de Assis Bandeira ${ }^{1}$

\begin{abstract}
The Ethnomathematics diffusion in the scope of basic education is still scarce, despite its proposals for the pedagogical action. In view of that, I present results from three research projects directed to the teaching of basic education under the light of the Dambrosian concepts of ethnomathematics. The first project looked at the mathematical knowledge familiar to potters living in the village of Currais Novos in the state of Rio Grande do Norte. The project looked at how to contribute to the elaboration of a pedagogical proposal dialoguing with formal mathematical knowledge taught in local schools. The second project is a report of an educational experience with 6th grade elementary school pupils living in a community of workers of red ceramic industries established in Russas, in the state of Ceará. The third project suggested a curricular analysis in mathematical education associating formal mathematics with the mathematical knowledge of a horticulturists' village located near Natal, in the state of Rio Grande do Norte. One of the results of the third research activity presented the pupils with the notion that mathematics exists not only in the class-room and in the books, but everywhere, and that it varies because cultures vary too. One pupil in the study knew both forms of mathematics: the academic school form, and the horticulturist mathematics, said that he preferred the latter because it was more familiar to him. Data from the second research activity revealed that, when pupils were responsible for the process of data collecting and analysis emerging from their own socio-cultural context, they added to their ability to create a discussion space in class-room, where the students turned to critical subjects found their own reality and social context. The proposal of the first research activity, was more of a qualitative character and used an ethnographical approach, and showed that when one works pedagogically with the mathematical knowledge of a certain village, and then tuning to academic mathematics, the pupil understands the meaning of this knowledge, even coming to value it.
\end{abstract}

KEYWORDS: Mathematics. Ethnomathematics. Apprenticeship. Teaching. Curriculum.

\section{RESUMO}

A difusão da Etnomatemática no âmbito da educação básica ainda é escassa, apesar de suas propostas para a ação pedagógica. É com essas preocupações que apresento três pesquisas direcionadas para o ensino de matemática da educação básica à luz das concepções dambrosianas de Etnomatemática. A primeira teve como objetivo investigar conhecimentos matemáticos dos oleiros do Povoado Currais Novos, Rio Grande do Norte, para subsidiar na elaboração de uma proposta pedagógica para dialogar com os conhecimentos matemáticos formais da escola daquele povoado. Na segunda pesquisa, faço um recorte ao apresentar um relato de uma experiência educacional empreendida com alunos 6으 ano do ensino fundamental provenientes de uma comunidade de trabalhadores de indústrias de cerâmica vermelha do município de Russas, no estado do

\footnotetext{
${ }^{1}$ Doutor em Educação Matemática - Universidade Federal do Rio Grande do Norte - Penedo, Caicó - RN - Brasil (UFRN). Professor do Departamento de Ciências Exatas e Aplicadas - CEA do Centro de Ensino Superior do Seridó (CERES/Caicó) - Universidade Federal do Rio Grande do Norte - Penedo, Caicó - RN - Brasil. E-mail: fabandeira56@gmail.com
}

Received on: 25/02/2017 - Accepted on: 31/05/2017

$\begin{array}{llllll}\text { (C) ETD- Educação Temática Digital } & \text { Campinas, SP } & \text { v.19 } & \text { n.3 } & \text { p.622-652 } & \text { jul./set. } 2017\end{array}$


Ceará. A terceira pesquisa propõe uma reflexão curricular em educação matemática ao associar a Matemática formal aos conhecimentos matemáticos de uma comunidade de horticultores da cidade do Natal, Rio Grande do Norte. Um dos resultados dessa terceira pesquisa mostrou aos alunos que a matemática não existe somente em sala de aula, a dos livros, mas também em qualquer lugar e que ela é diferente porque as culturas também são diferentes, como falou um dos alunos que entendia as duas matemáticas: a da escola e a da horta, mas esta era melhor porque já trabalhava com ela. A segunda pesquisa evidenciou que, ao colocar os alunos como os principais responsáveis pelo processo de coleta e análise dos dados provenientes de seu próprio contexto sociocultural, contribuiu para a criação de um espaço de discussão em sala de aula, colocando os discentes como sujeitos críticos de sua própria realidade. A proposta da primeira pesquisa, de caráter qualitativa em uma abordagem etnográfica, informa que ao trabalhar pedagogicamente os conhecimentos matemáticos daquele povoado em sintonia com a Matemática acadêmica, o aluno compreenderá o significado desses conhecimentos, além de valorizá-los.

PALAVRAS-CHAVE: Matemática. Etnomatemática. Aprendizagem. Ensino. Currículo.

\section{RESUMEN}

La difusión de la Etnomatemática en el área de la educación básica aún es escasa, a pesar de sus propuestas para la acción pedagógica. Es con esas preocupaciones que yo presento tres investigaciones direccionadas para la enseñanza de la matemática en educación básica a la luz de las concepciones dambrosianas de Etnomatemática. La primera tuvo como objetivo investigar conocimientos matemáticos de oleros del pueblo Currais Novos, Rio Grande do Norte, para subsidiar la elaboración de una propuesta pedagógica para dialogar con los conocimientos matemáticos formales de la escuela de dicho pueblo. En la segunda, presento un relato de una experiencia educacional emprendida con alumnos del sexto año de la enseñanza básica provenientes de un pueblo de trabajadores de industrias de olería bermeja del municipio de Russas, Ceará. La tercera investigación propone una reflexión curricular en educación matemática asociando la Matemática formal a los conocimientos de un pueblo de horticultores de la ciudad de Natal, Rio Grande do Norte. Uno de los resultados de esa tercera investigación ha mostrado a los alumnos que la Matemática no existe solamente en sala de aula, la de los libros, sino también en cualquier lugar, y que ella es diferente porque las culturas son diferentes. Como ha dicho un alumno que conocía las dos matemáticas: la de la escuela y la de la huerta, pero la última era mejor porque él trabajaba con ella. La segunda investigación ha evidenciado que, colocar los alumnos como principales responsables por el proceso de recolección y análisis de información provenientes de su propio contexto sociocultural, contribuyó para la creación de un espacio de discusión en el aula de clases, poniendo los estudiantes como sujetos críticos de su propia realidad. La propuesta de la primera investigación, de carácter cualitativo y con enfoque etnográfico, informa que trabajar pedagógicamente los conocimientos matemáticos de aquel pueblo en sintonía con la matemática académica, ha permitido a los alumnos comprender el significado de eses conocimientos, además de valorarlos más aún.

PALABRAS CLAVES: Matemáticas, Etnomatemáticas, Aprendizaje, Enseñanza, Currículum.

\section{INTRODUCTION}

Ethnomathematics is among the prevailing trends in mathematics education and looks towards a more relevant and critical perspective. Because it recognizes the validity of diverse forms of thinking and takes as its object of study many practices and knowledge forms, especially those concerning specific socio-cultural groups of different historical stages, Ethnomathematics has thrown in sharp focus some premises not questioned before and which were assigned to academic mathematics and highlights the importance of rescuing and re-connecting this science with sociocultural aspects.

(C) ETD-Educação Temática Digital Campinas, SP $\quad$ v.19 $\quad$ n.3 $\quad$ p.622-652 jul./set. 2017


This particular field of knowledge, which came to light in the mid-70s, has been very well received as a manner of explaining the mathematical relations inherent to an identified socio-cultural group. However, despite its many proposals for pedagogical action, its diffusion within the scope of basic education is still rare. The origin of such a difficulty lies perhaps in the resistance of some educators who seem indifferent to the influence of culture especially in the context of understanding mathematical ideas ${ }^{2}$.

The pedagogical conceptions in ethnomathematics has as a primary objective: to respect the other with all his/her differences, and to direct pedagogical actions that help us to listen to minority voices and to treat all pupils respectfully and equally as a form of constructing an educational focus adequate to transfer values of solidarity, justice and tolerance. In addition, this will help learners to become conscious about what he/she already thinks mathematically. Therefore, we can learn mathematics that conducts $\mathrm{him} /$ her to a new mode of conceiving this field of knowledge in view of the socio-cultural aspects of the environment.

The present article presents data and experience from three research projects in ethnomathematics associated with specific socio-cultural groups in the northeast of Brasil. The first research aimed at investigating mathematical knowledge of potters who lived in the village of Currais Novos, and sought to support an elaboration of a pedagogical proposal to enable a dialogue with formal mathematical knowledge of the school existing there. Data from the second work presents a report of an educational experience developed by 6th grade pupils in a elementary school in a village of red roofing tile workers in the municipality of Russas, in the state of Ceará. The third work offers a curricular reflection in mathematical education by associating formal mathematics with the mathematical knowledge of horticulturists in a village near Natal, in the state of Rio Grande do Norte.

\section{ETHNOMATHEMATICS IN A POTTERY IN SERIDÓ/RN}

The ethnomathematics related to pottery in the region of Seridó, in the state of Rio Grande do Norte, was defended in masters' work by Gilberto Cunha de Araújo Júnior in 2013, under my orientation, that investigated the mathematical knowledge of the potters ${ }^{3}$ of Currais Novos. He was mostly interested in the use of this knowledge in the production and commercialization of colonial pottery tiles. The Cerâmica Peruana (Peruvian Ceramic)

\footnotetext{
2"Mathematical ideas, particularly to buy, to classify, to quantify, to measure, to explain, to generalize, to infer, and, somehow, to evaluate, are forms of thinking present in all human kind" (D'AMBROSIO, 2001, p. 30).

${ }^{3}$ In the electronic Houaiss Dictionary of the Portuguese Language (2009), potter is the individual who manufactures or sells pottery objects; ceramist; he who works in a pottery atelier "plant". This refers to the place where pieces of pottery are manufactured; the technique of manufacturing clay objects; the potter's art.

(C) ETD-Educação Temática Digital Campinas, SP $\quad$ v.19 $\quad$ n.3 $\quad$ p.622-652 jul./set. 2017
} 
investigation field of Araújo Júnior (2013), is found in a district of Currais Novos called Jardim do Seridó, with an estimated population of 500 families which have been manufacturing and commercializing red ceramic tiles for their main income for many years. Their production is sold in Rio Grande do Norte and other northeastern states.

During the investigation period, 35 potters were working in Currais Novos, all of them male. Most of them did not complete secondary school studies, while others completed the elementary school, and a few of them only studied until the $5^{\text {th }}$ grade. Many of them work in the pottery industry due to scarce work opportunities in the region, or simply because their families wished it.

To achieve the research objectives, Araújo Júnior (2013) used as a reference Dambrosian concepts of ethnomathematics. As well, he employed qualitative research in his ethnographic approach (ANDRÉ, 2000). Indeed, besides investigating the mathematical knowledge of the potters in Currais Novos and the production and sale of tiles, under the light of ethnomathematics, he selected information to allow for further elaboration of a pedagogical proposal that developed dialogue with the formal mathematical knowledge of the town school.

In the visits this researcher made to Cerâmica Peruana, besides the analysis of photographs, interviews, a logbook, field annotations, observations, amid other documents, we identified the forms of mathematical knowledge in the manufacturing and sale of tiles, frequently differing from formal mathematics. In so doing we utilized and looked at the following activities: the method of counting tiles when loading trucks for transportation; in the moment of the purchase of the raw-materials needed to manufacture the tiles; when selling tiles; in the tile format, in the roof tile oven, in the tile storage sheds; in the calculation of the water volume that potters applied to mix with the clay; in the measurement at the time of purchase of the clay needed to make the tiles; in the firewood needed to feed the furnaces. For space limitation, however, only two of these activities will be described in detail here: the mathematical knowledge used in tile commercialization; and mathematical knowledge in the clay purchase and extraction.

\section{Mathematical knowledge in the tile commercialization}

Colonial red ceramic tiles as manufactured by Cerâmica Peruana, per Seu Luan Carlos (07/01/2012), is commercialized as follows: "First-rate tile costs one hundred and ninety [reais], second-rate tile, one hundred sixty [reais], and third-rate tile, thirty reais". By this explanation, one can interpret that the values of the first, second and third-rate tiles refers to groups of a thousand tiles each. The first and second-rate tiles are commercialized in

$\begin{array}{llllll}\text { (C) ETD- Educação Temática Digital } & \text { Campinas, SP } & \text { v.19 } & \text { n.3 } & \text { p.622-652 } & \text { jul./set. } 2017\end{array}$


Sergipe and Bahia states or, as Seu Luan explains (02/06/2011), the weekly production of Peruana Pottery goes " $80 \%$ to Bahia state and 20\% to Sergipe".

The customers are responsible for conveying on their trucks the tiles that they buy in Sergipe and Bahia, but the pottery workshop or factory is responsible for arranging them on the truck for shipment, a task that is performed by the potters themselves. The number of tiles depends on the seize of the truck. The truck represented in Figure 01 holds 18.000 tiles. The first layer or the carriage bucket of the truck holds around 10.000 tiles, and the second layer, 8.000.

Figure 1 shows five Cerâmica Peruana potters arranging tiles on a truck. While two potters are carrying tiles, other two receive and arrange the tiles in line, and the fifth counts them. The file counter is Seu Jailson Medeiros, and this is the only task he performs at the factory.

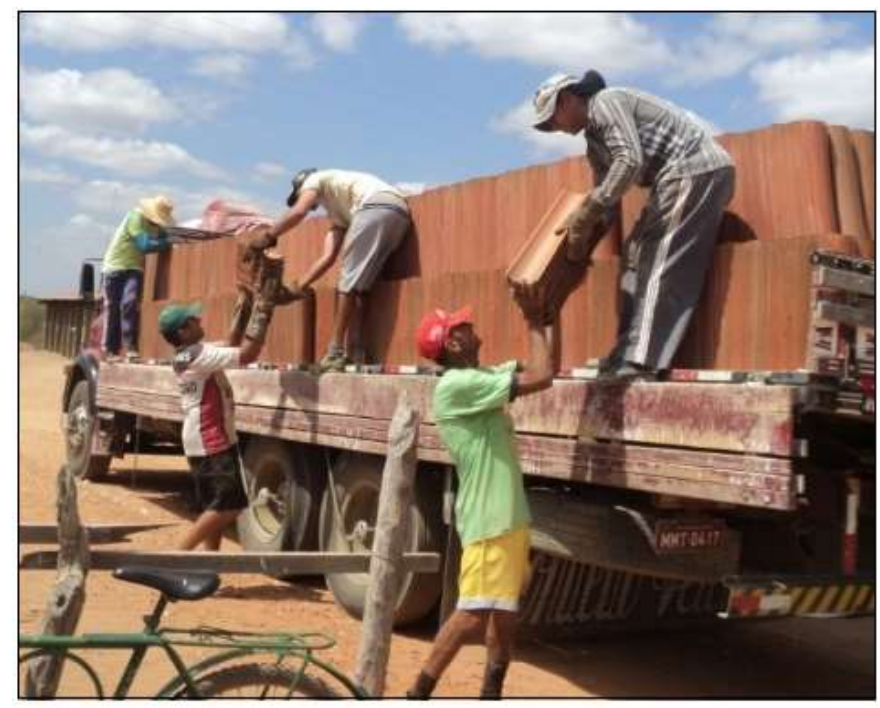

FIGURE 1 - Potters arranging tiles on truck Source: Araújo Júnior (2013)

What called our attention was the manner Seu Jailson counted the tiles. While the potters arranged the tiles in lines on the truck, Seu Jailson counted and registered each line on a tile register as if it were a notebook, as is shown in Figure 02. The counting of the first line occurs in rows. These rows vary in quantity, while the second row is always invariable. As Seu Jailson counts each tile row of the first tile layer, he registers this information in his notebook - that is, a tile, as it was before-mentioned, and each tile line or group varied from 503 to 548 tiles.

Interestingly, Seu Jailson registered only the tens and units on his register tile, while the hundreds are mentally registered. With the experience that he has in counting the tiles on each truck, he knows how many rows of tiles each one can transport. The truck showed in Figure 01 can carry 500 tiles, and then he uses only the number 500 and multiplies it by

$\begin{array}{llllll}\text { (C) ETD- Educação Temática Digital } & \text { Campinas, SP } & \text { v.19 } & \text { n.3 } & \text { p.622-652 } & \text { jul./set. } 2017\end{array}$


18 rows, totalizing 9.000 tiles. The other procedure, that is, the sum of tens and units, he realizes one by one with the aid of his electronic calculator.

As the second layer of tiles is always constant and, in the case of the truck showed in Figure 01, holds 15 rows of tiles, each one with 514 tiles, Seu Jailson realized then the multiplication with the aid of an electronic calculator, that is, $514 \times 15$, totalizing 7.710 tiles, as shows the register tile in Figure 02.

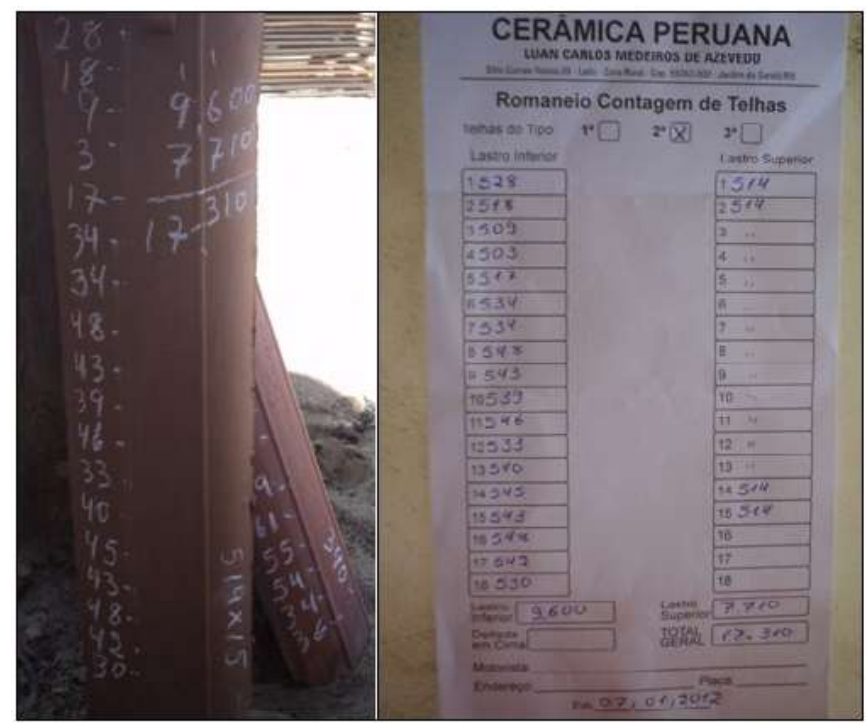

FIGURE 2 - Register of the count of tiles on the truck Source: Araújo Júnior (2013)

Seu Jailson then transferred the data registered on the tile to the romaneio ${ }^{4}$, as one can observe in Figure 02. The list contains the tiles in rows, in layers, and type of tile - if first, second or third-class, and the total of tiles loaded on the truck.

These counting procedures used by Seu Jailson to calculate the tiles reveal a form of decomposing of the quantity of the number of tiles, in hundreds, tens and units, different than what is taught in school, that is, first: units; second: tens; third: hundreds, always following this sequence. According to Seu Jailson (10/02/2012), the procedure he applied during the counting of the tiles, "is simpler and more rapid to make the calculations".

\footnotetext{
${ }^{4}$ Romaneio, in Houaiss Electronic Dictionary of the Portuguese Language (2009), means a list specifying weigh, quality and amount of merchandises shipped or sold. By extension and informal usage, it means also a complete and detailed list.

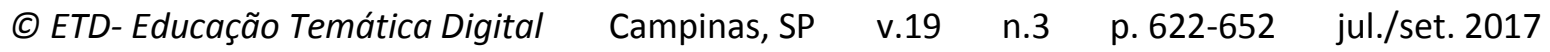


In the work done with youth and adults as part of the Landless Rural Workers movement (MST) in Veranópolis, in the state of Rio Grande do Sul, Knijnik (2000) elaborated a cultural method that the laborers used to make sums.

To the sum strategy in the wake of the decomposition of orally computed values, first the most graduated ranks. This happened with a Capacitation Workshop trainee realized in Viamão, when, before a situation that requested him to count $148+238$, he explained that, "at first, we separate everything $[100+40+8$, and $200+30+9]$ and then sums what values more [ $100+200,40+30,8+9]$. (..) That is [what values more] what counts". This strategy was often found among all the adults that defined themselves as "good in head's calculations". Contrary to the addition algorithm taught in school, in the oral procedures laborers considered, above all, the values of each parcel that were on stake and how different would result to treat hundreds, tens and units, that is, he gave preference to values that contributed more markedly to the result (p.10).

As can be perceived, to use mental calculations in addition operations that the socio-cultural members of the landless Rural Workers needed to organize the numbers in ranks, that is, tens and units, and then, gave preference to the set of the operation by minor degree ranks. The applied procedures used by Seu Jailson to count the Cerâmica Peruana's tiles did not differ from the method of these peasants, behind-mentioned. Because the socio-economic groups are diversified as well as their knowledge, it is worth mentioning that the Seu Jailson's method in counting tiles is not the only method known.

\section{Mathematical knowledge in the clay purchase and extraction}

The clay needed by the potters used is found in reservoirs and rivers. They accomplish all the extraction of the clay near the dam. To this purpose, they carry out the clay cubage ${ }^{5}$ that will be commercialized by the dam's proprietor. In other words, to know the clay amount that the potteries' proprietors intend to buy in a dam, first they analyze the clay's condition and then delimit the necessary amount in square format, in so doing they estimate the clay's depth adequate to tile manufacture. After this is done, they negotiate with the dam's proprietor.

Below is one description of these moments, in the words of Seu Luan Carlos (23/04/2016), owner of the Cerâmica Peruana, about this procedure:

\footnotetext{
${ }^{5}$ Cubage is a procedure typically algorithmic used by rural workers of Rio Grande do Norte and other northeastern states of Brazil in the surveying practice. As Del Pian, apud Gomes (1997, p. 206) says, "this procedure is routinely used since the colonial days, as part of the farming work". The term cubage is also used in the process of calculation of the volume of wood "toras" (logs) (GRANDO, 1998). In the Cerâmica Peruana workers' context, cubage means the volume calculation of a certain red tile amount of clay.
}

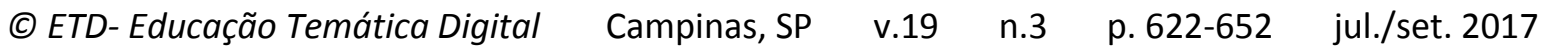


How do you proceed in the purchase of clay?

- The business is as follows, the motorist of the bucket truck sees if the mud [clay] is good or bad, then he delimits a square area, OK? [drawing the form of a square in the notebook]. Then he multiplies the square sides in depth, and finally he knows how much clay he needs. Thereafter, all he needs to do is load the truck and carry the clay in the big dumptruck. Each loading has its own price. A loaded bucket costs eighty, seventy, price varies because the filler is ours; he only pays for the clay, not the filler.

How do you know how much you will pay for the clay you take from the dam?

- Well, as you know the clay amount you want, so you divide it by the bucket load, then you multiply it by the bucket load price and you will know how much more or less you will pay for the mud.

The clay cubage procedure was proved in loco in one of the researcher's visit, in 2012, to Ouro Branco, in the state of Rio Grande do Norte, when he stayed by the Manoel de Brito reservoir, where the potters often extract the clay need. Let us see now the procedure of volume measurement and clay purchase was realized in the reservoir by Cerâmica Peruana workers.

At the reservoir, it is the driver of the bucket truck who assesses at first if the clay is good or bad, because he is the person in charge of transport it to the workshop. After assessing the clay with his naked eye, he counsels potters on the delimitation of the area on which they will work to get the clay, generally in the form of a square at the dam's edge. To delimit and calculate the volume of the clay and the extraction area, potters use the following tools: a 25 meters long measuring tape, an electronic calculator and four wood stakes.

At first, potters place one stake at the dam's edge and, with the aid of the measuring tape, they measure 25 meters, then they place another stake. To delimit the third stake, potters do not use any precision tool to assess if the delimited side forms a $90^{\circ}$ angle with the constructed side; they only estimate the perpendicularity with the naked eye. To place the fourth stake, they follow the same procedure with the latter one, however, adjusting it with the other sides of the square format, if necessary. This way, they create a design in the form a square on the ground.

If the square's side measures $25 \mathrm{~cm}$, the calculation of this area realized by the potters, with the aid of an electronic calculator, was $625 \mathrm{~m}^{2}$. To value the clay volume of the reservoir, which is good to manufacture tiles, potters estimate a certain depth, on the dependence of the dam, reservoir or river's' depth. In the referred reservoir, the depth of good clay, in accordance with the potters, was estimated as about two meters in depth. After all the procedures were done, the potters multiplied the region area delimited by the

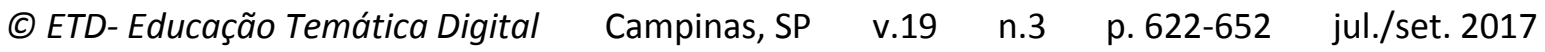


estimated depth, with the aid of an electronic calculator like follows: $625 \mathrm{~m}^{2}$ of the area multiplied by two meters' depth, resulting in $1.250 \mathrm{~m}^{2}$.

In this context, $1.250 \mathrm{~m}^{2}$ was the calculated volume concerning the estimation of good-quality clay that could be extracted from the delimited area. To calculate the value in real currency to be paid for the clay, the potters divided the volume by the capacity of the bucket truck, resulting in the number of buckets to be carried from the reservoir to the Cerâmica Peruana.

It is worth mentioning here that the capacity calculation of the Cerâmica Peruana's bucket truck, which has the format of a regular prism, was calculated by the interior volume of the bucket. Then, let us denominate $\mathrm{V}_{1}$ = bucket's capacity; $\mathrm{a}=$ bucket's length; $b=$ bucket's length, and $c=$ bucket's height. The following measures were verified in the bucket by Araújo Júnior (2013), in which $a=4 \mathrm{~m}, \mathrm{~b}=2 \mathrm{~m}$, and c = $2 \mathrm{~m}$, obtaining, this way, the bucket's capacity, in volume, in the following way:

$$
V_{1}=a \times b \times c \rightarrow V_{1}=4 m \times 2 m \times 2 m \rightarrow V_{1}=16 m^{3}
$$

Therefore, $16 \mathrm{~m}^{3}$ is the volume of clay that the bucket truck of the Cerâmica Peruana can bear in each trip. To calculate the value to be paid to the owner's reservoir, the potter makes a calculation dividing the estimated value of clay to be extracted by the volume that represents the capacity of clay that the bucket can carry in the following way: $\mathrm{C}=$ total number of buckets; $\mathrm{V}=$ volume of clay to be extracted; $\mathrm{V}_{1}=$ capacity, in volume, of clay that the bucket conveyed in a trip:

$$
C=\frac{V}{V 1} \rightarrow C=\frac{1.250 \mathrm{~m}^{3}}{16 \mathrm{~m}^{3}} \rightarrow C=78,125 \text { buckets }
$$

This total is rounded for 78 buckets, because the potters say that what is taken in consideration is the bucket full of clay. With this, the value to be paid to the reservoir's owner is calculated this way: 78 buckets multiplied by $R \$ 80,00$ that is the price of a bucket full of clay, totaling R\$ $6.240,00$.

The interpretation of the collected clay extraction and cubage data by the sociocultural group, the Cerâmica Peruana workers, brings, as Knijnik said (2006, p. 70), "a reflection about the importance given by the group to the apprenticeship of measuring the land motivated by a real and undisputable need of solving daily life questions of the workers' [potters'] productive sphere".

(C) ETD-Educação Temática Digital Campinas, SP $\quad$ v.19 $\quad$ n.3 $\quad$ p.622-652 jul./set. 2017 
In the perspective of using the mathematical knowledge of the potters to help pupils in Currais Novos, Araújo Júnior elaborated, as pedagogical proposal, activities related to the cubage of clay, as shown below. It is worth saying that Gerdes (1991) and his pupils investigated how Mozambican people raised the foundations of their houses. After interviews and conversations with villagers, they arrived at the conclusion that they used strings and bamboo rods to raise the perpendicular foundation of their houses.

Therein, the diagonals are composed of strings with the same length, and the sides are formed by bamboo rods and adjusted as to represent a triangle. By the way, this method does not different greatly of the potters' procedures to trace the representation of a square adjusting its sides at the naked eye. Paraphrasing Rosa and Orey (2009), potters found a hidden mathematics in their own culture when they discovered and explored the ethnomathematical knowledge present in the proper reality.

Araújo Júnior (2013) said that, by the commentaries he heard among the potters in informal conversations, and by the instruction degree they have, they had not had the chance to study formal Spatial Geometry in school, so this knowledge was acquired in daily work and contexts. After the description of these two activities of the worker of the Cerâmica Peruana, Araújo Júnior (2013) directed these activities to an educational proposal to be developed in potters' community schools in the Seridó region, especially in Currais Novos.

That is what follows below:

Mathematics in the tile commercialization

Target public: $5^{\text {th }}$ to $9^{\text {th }}$ graders students.

Objectives

- Recognize the decimal numeration system.

- Use the four fundamental operations of academic Mathematics in the counting of tiles.

Content

- The decimal numeration system.

- The four fundamental operations in academic Mathematics.

- The simples rule of three.

- Notion about cost. 
Procedures

1. The teacher should take the pupils to visit the Cerâmica Peruana to observe as the potters organize the tiles on the trucks.

2. To ask pupils to annotate the necessary procedures in the organization of the tiles on the trucks.

3. Finished the data collection, to work the following activity and/or like that.

Text

The colonial red pottery tiles manufactured in the Cerâmica Peruana are stocked to commercialization, after being selected. In general, the tiles are sold to Rio Grande do Norte state's neighbors. The owners of the Cerâmica Peruana sell the tiles in lots, each one containing 1.000 tiles. The price of each lot depends on the tile's quality, as is shown on Table 1.

TABLE 1 - Prices and quality of the tiles of the Cerâmica Peruana

\begin{tabular}{|c|c|}
\hline $\begin{array}{c}\text { Quality of the tiles of the } \\
\text { Cerâmica Peruana }\end{array}$ & $\begin{array}{c}\text { Price paid in real currency for } \\
\text { a thousand tiles }\end{array}$ \\
\hline First-rate & $\mathrm{R} \$ 190,00$ \\
\hline Second-rate & $\mathrm{R} \$ 160,00$ \\
\hline Third-rate & $\mathrm{R} \$ 30,00$ \\
\hline
\end{tabular}

Source: Araújo Júnior (2013)

On January 2012, the owners of the Cerâmica Peruana closed a sale of 17.000 second-quality tiles with a customer from Bahia State. To compensate disparage and breaking of tiles during the long trip to Bahia, 310 tiles were added at the sale. Based on the text and the figure above, answer:

a) How much, in real currency, did the owner of the Cerâmica Peruana receive by the sale closed with the customer from Bahia State?

b) If the customer hand bought the double number of second-quality tiles, how much would he pay in real currency?

c) Suppose that in the sale closed with the Bahia customer the total of tiles was 17.000 , being 10.000 first-rate and 7.000 second-rate. How much would he pay in real currency?

d) A second customer made the following purchase: 5.000 first-rate tiles, 7.000 second-rate and 5.000 third-rate. How much in real currency did this customer pay to the owner of the Cerâmica Peruana?

e) Analyze Figure 03 and answer: it is more profitable to sell 2.000 first-rate tiles or 1.100 first-rate and 1.000 second-rate tiles? Justify your answer.

(C) ETD-Educação Temática Digital Campinas, SP $\quad$ v.19 $\quad$ n.3 $\quad$ p.622-652 jul./set. 2017 
f) A customer purchased 5.000 second-rate tiles and another customer purchased 6.000 second-rate tiles. Which of them expended more money in the purchase, in real currency?

Suggestions of some subjects to be analyzed in class-room:

- The teacher can work with several numeration systems.

- He can also use the decimal abacus to practice ludically the four fundamental operations.

The teacher worked with their students in the way of counting that the potters did with tiles and the romaneio. The accountability of tiles is done in lines, but not using the hundreds, because potters register commonly the tens and round down to lower truck ballast. To the upper ballast, the number of tiles in each line is constant. After this description, the potter transfers the data to romaneio, as one can see in figure 3 .

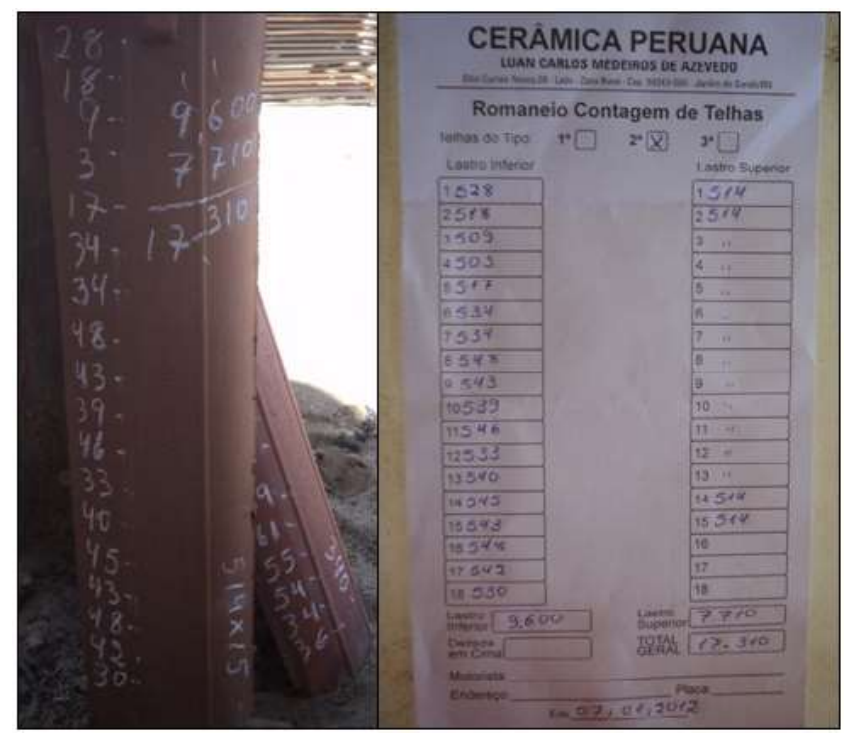

FIGURE 4 - Before-mentioned as figure 3 Source: Araújo Júnior (2013)

Mathematics in clay purchase and extraction

Target public: $9^{\text {th }}$ graders students.

Objectives

- To practice the potters' geometric knowledge to perform the reading and representation of reality and act over it;

- To build notions of magnitudes and measures to capture reality and the solution with routine problems;

- To work the idea of area in plane figures and volumes in polyhedron;

(c) ETD-Educação Temática Digital $\quad$ Campinas, SP $\quad$ v.19 $\quad$ n.3 $\quad$ p.622-652 $\quad$ jul./set. 2017 
- To introduce the calculation assessment of the clay cost, adding multiplication and division of whole and decimal numbers with socio-cultural knowledge.

Content

- Plane figures (square and rectangle);

- Polyhedron volumes;

- Whole and decimal numbers;

- Costs.

\section{Procedures}

1) The teacher must have realized a review of the measure units;

2) To review the concept of plane figures and the area calculation;

3) To show the pupils several types of polyhedrons and how to calculate their volume.

Text

Potters use to buy and extract clay behind dams sometimes far or distant from Cerâmica Peruana. The clay extraction follows this procedure: the potter and bucket truck driver assesses if the clay is high enough in quality to meet the manufacturing standards necessary for the tiles.

The potters then outline a square in the soil. After this, he calculates the area of this square. To calculate the volume of clay to be extracted, he estimates depth and profundity using the naked eye taking as base the delimited square in the soil. Then he multiplies the area of this square by the estimated depth. In Ouro Branco, in the state of Rio Grande do Norte, the workers of the Cerâmica Peruana outlined a square with sides six meters long and estimated the clay depth as two meters.

Thereafter, he multiplied the squared delimited area in the soil by the depth estimated, and figured it to be about $72 \mathrm{~m}^{2}$. To know the amount in real currency to be paid for the extracted clay, he took as unit measure a $16 \mathrm{~m}^{2}$ bucket. As each clay-loaded bucket cost $\mathrm{R} \$ 80,00$, the potter divides the total estimated volume of clay to be extracted, measuring $72 \mathrm{~m}^{2}$ per $16 \mathrm{~m}^{3}$. Then he reaches the volume of 4,50 clay buckets. As the number of buckets was not exact, the potters dispense with the decimal digits. In this sense, they consider only four clay buckets. Thus, the value to be paid to the dam's owner will be $\mathrm{R} \$ 320,00$.

Based on the present text, answer:

a) How much would four complete clay buckets cost in relation to the conditions presented above?

(C) ETD-Educação Temática Digital $\quad$ Campinas, SP $\quad$ v.19 $\quad$ n.3 $\quad$ p.622-652 jul./set. 2017 
b) Suppose that a potter outlines a square measuring eight meters a side. Which is the area of the region to be worked on?

c) Considering the last question and the depth estimated by the potter in the text, which is the volume of clay estimated, in cubic meters?

d) How many bucket truck loads will be necessary to transport all clay estimated in the last question?

e) How many reais will the Cerâmica Peruana's owner pay to the dam's proprietor, considering the number of buckets in the last question?

f) The Cerâmica Peruana's owner paid $\mathrm{R} \$ 800,00$ for a certain amount of clay extracted. How many buckets were necessary for the transport to reach the value paid? (Consider the text above).

g) Considering the last question and the text above: which is the total volume of clay to be extracted in cubic meters?

\section{THE ETHNOMATHEMATICS OF THE POTTERY WORKERS IN RUSSAS, IN THE STATE OF CEARÁ, AND THE SCHOOL CONTEXT: SKETCHING PEDAGOGICAL ADVICES BASED ON AN EDUCATIONAL EXPERIENCE}

The ethnomathematics of the pottery workers in Russas, in the state of Ceará, and the school context: sketching pedagogical advices based on an educational experience is a dissertation work defended by Paulo Gonçalo Farias Gonçalves, in 2013, under my orientation that tried to develop an intervention with the learners in the school coming from the village that connected the ethnomathematical knowledge common in the workers' practices to the school mathematics content.

The village of workers of the tile industries, forms the research field of Gonçalves (2013) and from the town of Russas, near Fortaleza, in the state of Ceará, and has a population of about 75.000 inhabitants. As one of the main economic activities of the town, the red tile industries, or simply cerâmicas, as they are popularly known, have made this municipality an important manufacturer of tiles and bricks for the entire northeastern region of Brazil. Gonçalves developed his research at the Seu Benoni workshop about $7 \mathrm{~km}$ from Russas.

The research subjects of this author were $6^{\text {th }}$ graders at the school in 2012 . These students were chosen because their class was made up mostly of students/workers of the ceramics. The class was formed by adolescents from 12 to 17 years of age; nine of these students, though in a legally inadequate age, also worked in the regions' cerâmicas after

(C) ETD-Educação Temática Digital $\quad$ Campinas, SP $\quad$ v.19 $\quad$ n.3 $\quad$ p.622-652 jul./set. 2017 
school. In addition, all of them had some relative experience working in the regions' industries.

\section{Pedagogical Process}

Making use of the field research as a pedagogical action, the students mediated by the teacher/researcher succeeded in characterizing and identifying four ethnomathematics practices related to the labor in the ceramic workshops, that is: counting of and the manufacturing of bricks and tiles and stacking these bricks and tiles on trucks. These ethnomathematical practices were systematized by the students under the direction of the researcher/teacher verifying similarities and peculiarities concerning traditional school knowledge included in the $6^{\text {th }}$ grade curriculum of the school that served as foundation for the activities related to the ethnomathematics knowledge of the workers and to formal school content: multiplication, introduction to proportionality and division.

The development and application process of educative intervention held by Gonçalves (2013) was based on the following steps: 1) research preparation; 2) field research and data analysis; 3) activity planning; and 4) activity application. In the sequence below the aspects inherent to each of these steps will be put in discussion. The educational intervention started with a first step named research preparation. It helped students to meet the environment where they would work and prepare them to handle the data collection tools necessary to the field research. In this circumstance, if necessary, the teacher should try to know better the socio-cultural context to be investigated during the classes.

The following intervention step was essential to the development of the field research and data analysis. This second step was structured as interconnected moments. In fact, the first moment focused all the functioning process of the potteries and the production stages of tiles and bricks. This stage marked the moments in which ethnomathematics knowledge played an auxiliary role in the manufacturing of tiles and bricks. The second moment focused the observation and analysis of the following production stages: counting of the production of tiles and bricks and their loading on trucks. This moment culminated with the systematization of the ethnomathematical knowledge during these stages.

The third stage, includes an Activity Plan, and highlighted the teacher's actions. It appeared as a transition and relation phase between the ethnomathematical knowledge applied by the workers and the contents of school mathematics presenting similarities

(C) ETD-Educação Temática Digital Campinas, SP $\quad$ v.19 $\quad$ n.3 $\quad$ p.622-652 jul./set. 2017 
with that knowledge. This moment culminated with the elaboration of four activities, interconnected two by two, according with the ethnomathematical knowledge of the potteries' workers and the school mathematics, prioritizing the school contents concerning multiplication, introduction to proportionality and division algorithm, as shown in the Square 1 below.

TABLE 2 - Synthesis of knowledge and contents of the school activities

\begin{tabular}{|l|l|l|}
\hline Activity & Relating knowledge & \multicolumn{1}{|c|}{ Relating school contents } \\
\hline Activity 1 & Ethnomathematics & Multiplication and introduction to proportionality \\
\hline Activity 2 & School Mathematics & Multiplication and introduction to proportionality \\
\hline Activity 3 & Ethnomathematics & Division algorithm \\
\hline Activity 4 & School Mathematics & Division algorithm \\
\hline
\end{tabular}

Source: Gonçalves (2013)

The activity application was the last stage of the experience. The first worked themes at this fourth stage were Multiplication and introduction to proportionality. The following is a outline of some of the problem situations at this stage were developed by Gonçalves (2013).

One of these problem situations refer to the teaching of multiplication, which began with a practical problem elaborated from the procedure of counting the production of bricks in Mr. Benoni's workshop. This ethnomathematical usage by the potters is based on the multiplication of the number of bricks counted in the three dimensions: length, width and height. See the problem situation proposed to $6^{\text {th }}$ graders of the school of the José Eduardo de Matos Municipal School.

Besides the tiles, the tile or ceramic industries in Russas, in the state of Ceará, also manufactured bricks. Normally, bricks are joined in equal lines, put side by side to make the counting of the production easier. After a pre-determined number of layers, new layers are placed over the first ones. Thereafter, at the end of production, a geometric figure, not unlike a rectangular cobble, as shown in the Figure 4.

In Mr. Benoni's workshop an average day produces of bricks gathered in the following form: 64 bricks in each line, named length in the mathematical formal language; 11 lines placed side by side over each of the latter lines that can be named, or in the mathematical formal language $=$ height. Based on the information presented, how many bricks have been manufactured that day?

(c) ETD-Educação Temática Digital $\quad$ Campinas, SP $\quad$ v.19 $\quad$ n.3 $\quad$ p.622-652 $\quad$ jul./set. 2017 


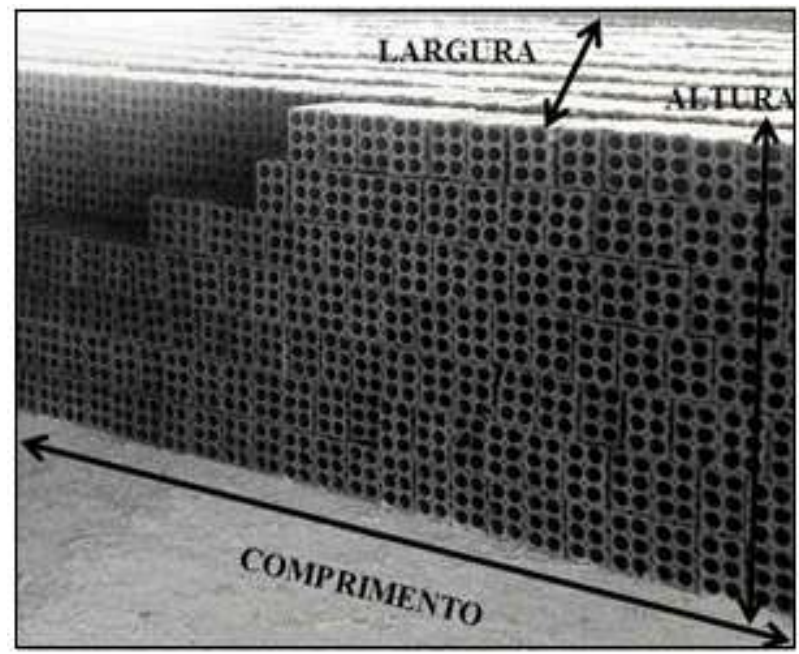

FIGURE 4 - Problem Generator

Source: Gonçalves (2013)

About the performance of the 19 students' class to the resolution of the problem above, eight answered the question correctly, taking as resolution strategy successive multiplications of the values, while four students elaborated right strategies to solve the question, but erred in the actual multiplication. The others made mistakes when resolving the problem or left it without any response.

The stage of contents' formalization used problems concerning the several ways of understanding multiplication. Gonçalves (2013) began approaching the general character of the counting process of brick manufacturing, which he named as: To count elements in $a$ cobble organization. This approach, inspired in the experience of the pottery's workers, constituted the most general case of another multiplication affair brought about by a didactic book of the $6^{\text {th }}$ grade school and that was examined during the school activity, named: To count elements in a rectangular organization.

While the activity was held, working students and non-students from the village faced the same difficulties in resolving the problem. João gathered some paper boxes of the same size from his store. Each stack of boxes looked like the drawing of the following Figure 5. Three questions for you:

a) How many boxes are there in a stack?

b) If there were nine stacks with the same number of boxes, how many boxes would be stocked at João's store?

c) If John owned 48 boxes, how could he stack these boxes to form a stack resembling a cobble? Do not forget, please, of enumerating the number of boxes existing in length, in width and in height of this new stack.

(C) ETD-Educação Temática Digital Campinas, SP $\quad$ v.19 $\quad$ n.3 $\quad$ p.622-652 jul./set. 2017 


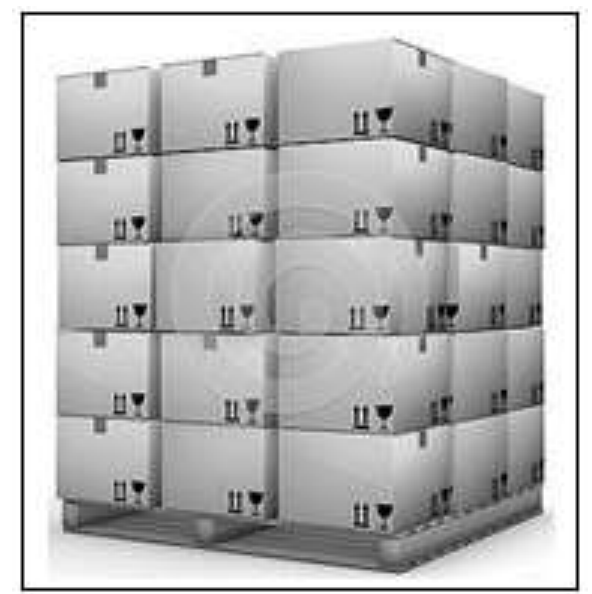

FIGURE 5 - Paper box stacking

Source: Gonçalves (2013)

The most frequent mistake made by nine of the 19 students was the item (a), that is, how many boxes are there in a stack? These students counted only the visible boxes in the image in perspective as the total of the stack. This erroneous interpretation also led them to fail the following question, that is, the (b) question, although they used the right procedure to its resolution.

The last question, the (c) one (Figure 6), which admitted more than one answer, presented the fact that six of the 19 students attributed to three dimensions of the boxes: length, width and height, values whose sum resulted in the total of the boxes, that is, 48 boxes, and that was not the case asked in the problem. Figure 7 presented another frequent error made by three of the 19 students.

c) If John owned 48 boxes, how could he stack these boxes to form a stack resembling a cobble? Do not forget, please, enumerating the number of boxes existing in length, in width and in height of this new stack.

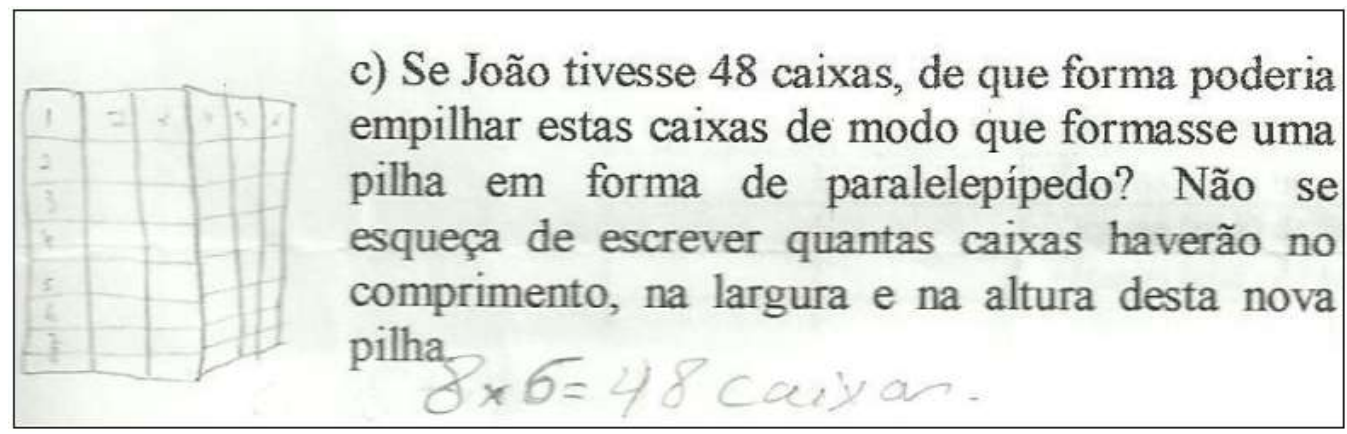

FIGURE 6 - Answer given by a $6^{\text {th }}$ grader student Source: Gonçalves (2013)

(c) ETD-Educação Temática Digital $\quad$ Campinas, SP $\quad$ v.19 $\quad$ n.3 $\quad$ p.622-652 $\quad$ jul./set. 2017 
As can be observed, the students' error consisted in taking the product of two dimensions as sufficing data to apprehend the total number of boxes in the stack.

\section{ETHNOMATHEMATICAL PEDAGOGY: ACTIONS AND REFLECTIONS IN FUNDAMENTAL SCHOOL MATHEMATICS WITH A SPECIFIC SOCIO-CULTURAL GROUP}

Ethnomathematical Pedagogy: actions and reflections in school mathematics with a specific socio-cultural group was the title of my doctoral dissertation, finished in 2009, which developed a pedagogical proposal of curricular reorientation in mathematics education for an elementary school. It was elaborated with the mathematical knowledge existing in the horticulturist village of Gramorezinho, Natal, in the state of Rio Grande do Norte, and in line with formal mathematics. This academic work is now a book (BANDEIRA, 2016).

Gramorezinho is a village situated on the coast north of Natal. Most people live mainly on the informal work of growing and selling vegetables (lettuces, coriander, spring onion, red peppers etc.) in supermarkets and free markets around the greater Natal metropolitan region. The vegetables growing in the village are distributed among small family estates. These family estates are vegetable gardens irrigated with water coming from a common water reservoir, fertilized with manure bought from nearby aviaries. The areas rarely contain more than 90 plots. A plot, in the language of the village, means a rectangular piece of land, measuring around two meters large by 20 meters long which is used to grow vegetables, especially coriander, lettuce and spring onions. A set of furrows is named or called a vegetable garden.

Most horticulturists in the village attended less than five years of school. The youngest ones, some of them horticulturists' children, gave up studying before finishing elementary school. The horticulturists' children, in preschool age, attended the only school in the village for the first and second grades. In the second semester 2007, I acted as teacher/researcher in the $5^{\text {th }}$ grade of the school with the aim of dialoguing with the students about a proposal of curricular reorientation in mathematical education, elaborated with the mathematical knowledge developed in that village, in line with the formal mathematical knowledge of the school (BANDEIRA, 2009).

The work developed in the above-mentioned school had two interconnected and opposite aspects: bring to class-room the traditional practices present in the village and, at the same time, lead students to visit the village gardens to experience the vegetable

(C) ETD-Educação Temática Digital Campinas, SP $\quad$ v.19 $\quad$ n.3 $\quad$ p.622-652 jul./set. 2017


garden context. Thereby, the pedagogical process was worked in blocks of contents proposed by the National Curriculum Parameters: Numbers and operations, Space and Form, Greatness and measures, and Information treatment in line with the mathematical knowledge of the horticulturists' village.

They were categorized as: Counting procedures, Length and area measurement, Volume measurement, Time measurement, Proportionality and commercialization. Due to space constraints, I will pay attention to Space and Form, Length and area measurement, Greatness and Measures and Volume measurement.

Space and Form and Length and areas measurement

The learning dimension of Space and Form gains relevance along with the role of geometry in the mathematics curriculum, especially in the first and second grade of primary school. Considering that geometry can lets those pupils understand the world in which they live, learning how to describe it, represent it and situate themselves in it. In addition, working with geometric notions encourages the learner to observe, to perceive similarities and differences, to identify regularities; it also permits the establishment of connections between mathematics and other areas of knowledge, inserting the exploration of objects taken from the physical world for the context of the classroom.

Considering that the geometric conceptions are mental representations that do not take part of real world, the great challenge of learning formal geometry is: how to transition from the concrete representation a mental representation? To achieve this target, the Curriculum National Parameters of primary school insist that students should be given activities that include the exploration, representation, interpretation and description of these spaces (BRASIL, 1997).

The geometric forms existing in the vegetable gardens, especially the furrows and plots constructed to growing vegetables, offer them some concrete examples available as objectives in the learning of geometry. These representations form the real context for children growing up in the context of the village of Gramorezinho. As Figure 7 shows below, the furrows have defined geometric forms, in fact, rectangular forms, that enable the teachers to work with this and other geometric concepts with the aid of geometric conceptions used by the village's horticulturists.

(C) ETD-Educação Temática Digital $\quad$ Campinas, SP $\quad$ v.19 $\quad$ n.3 $\quad$ p.622-652 jul./set. 2017 


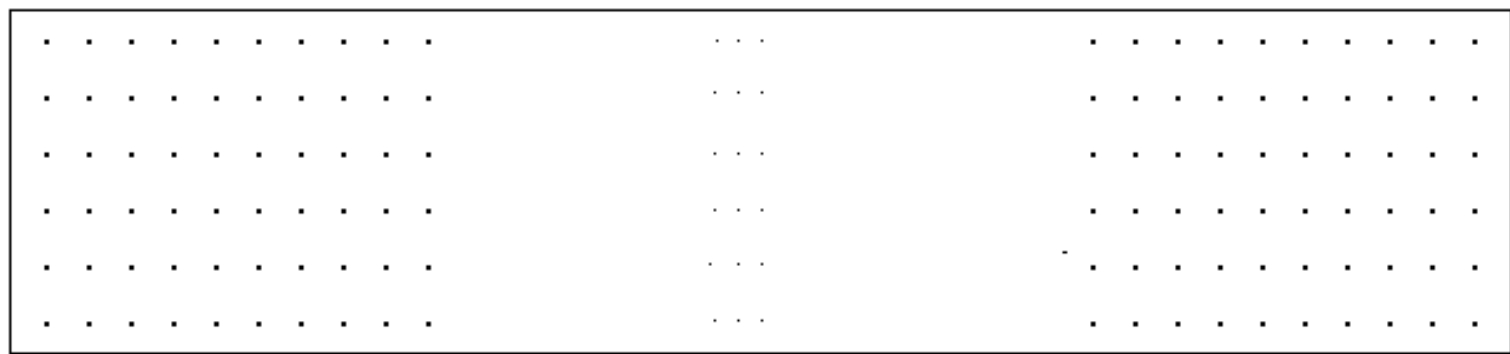

FIGURE 7 - A representation of the furrows developed in Gramorezinho village (Natal-RN) by the horticulturists. Dots represent seedlings of lettuce, separated by each other for approximately a horticulturist's span.

Source: Bandeira (2009)

To be more exact, the geometric conceptions of the horticulturists appeared in the moment they elaborated the plots and when they planted the vegetables calculating the spacing of the seedlings need. This spacing, in the case of the planting of lettuces, means a hand span separating the seedlings. The procedure amounts to a square of all the plots with small squares. As the plant are not placed in the corners, but in the center of the squares, as Figure 8 shows, each little plant has an area of a span by a span in which to grow. Thus, the area occupied by the seedling is preserved with the aid of linear measures, and is simpler to calculate.

\begin{tabular}{|c|c|c|c|c|c|c|c|c|c|c|c|c|c|c|c|c|c|c|c|}
\hline$\bullet$ & $\bullet$ & $\bullet$ & $\bullet$ & $\bullet$ & $\bullet$ & $\bullet$ & $\bullet$ & $\bullet$ & $\bullet$ & $\bullet$ & $\bullet$ & $\bullet$ & $\bullet$ & $\bullet$ & $\bullet$ & $\bullet$ & $\bullet$ & $\bullet$ & $\bullet$ \\
\hline$\bullet$ & $\bullet$ & $\bullet$ & $\bullet$ & $\bullet$ & $\bullet$ & $\bullet$ & $\bullet$ & $\bullet$ & $\bullet$ & $\bullet$ & $\bullet$ & $\bullet$ & $\bullet$ & $\bullet$ & $\bullet$ & $\bullet$ & $\bullet$ & $\bullet$ & $\bullet$ \\
\hline$\bullet$ & $\bullet$ & $\bullet$ & $\bullet$ & $\bullet$ & $\bullet$ & $\bullet$ & $\bullet$ & $\bullet$ & $\bullet$ & $\bullet$ & $\bullet$ & $\bullet$ & $\bullet$ & $\bullet$ & $\bullet$ & $\bullet$ & $\bullet$ & $\bullet$ & $\bullet$ \\
\hline$\bullet$ & $\bullet$ & $\bullet$ & $\bullet$ & $\bullet$ & $\bullet$ & $\bullet$ & $\bullet$ & $\bullet$ & $\bullet$ & $\bullet$ & $\bullet$ & $\bullet$ & $\bullet$ & $\bullet$ & $\bullet$ & $\bullet$ & $\bullet$ & $\bullet$ & $\bullet$ \\
\hline$\bullet$ & $\bullet$ & $\bullet$ & $\bullet$ & $\bullet$ & $\bullet$ & $\bullet$ & $\bullet$ & $\bullet$ & $\bullet$ & $\bullet$ & $\bullet$ & $\bullet$ & $\bullet$ & $\bullet$ & $\bullet$ & $\bullet$ & $\bullet$ & $\bullet$ & $\bullet$ \\
\hline
\end{tabular}

FIGURE 8 - Representation of a plots from the horticulturists' village of Gramorezinho (Natal-RN). The dots represent the lettuce seedlings and are separated from each other by a farmer's span. Source: Bandeira (2009)

My intention was to work with the $5^{\text {th }}$ graders of the school within these local contexts to lead them to perceive the many ways of calculating geometric figures. In other words, there are several ethnomathematical forms of reading the world, and these forms can be used in each context. In this regard, I elaborated two pedagogical activities relating to the vegetable garden and the study of the rectangle and notions of the area of geometric figures, as shown below. 
The first activity, concerning the vegetable garden and the study of the rectangle, composed of a text and questions about it, and read: To construct the plot, the horticulturists used to lay pottery tiles around each plot. In each corner they place wooden approximately, sticks 50 centimeters long, as one sees in figure 9.

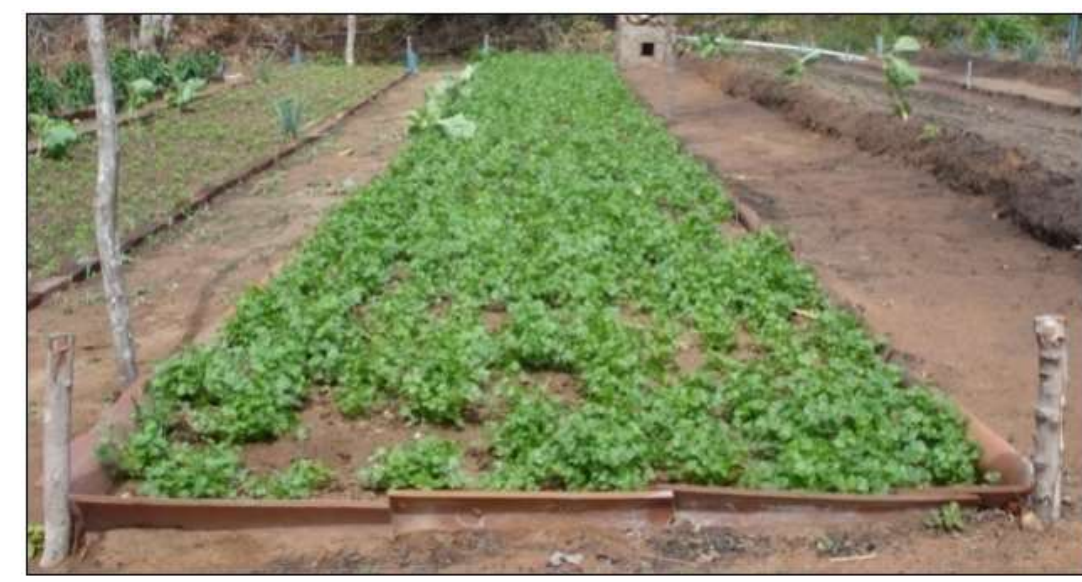

FIGURE 9 - A furrow from horticulturists' Gramorezinho village made of pottery tiles and four wood sticks.

Source: Bandeira (2009)

The contours of the furrow are called bordas (borders), what in mathematics are called "sides". The wood sticks placed in the corners of the plot are called tornos (lathes); in mathematics, vertexes. The encounter of the border with the lathe is called, in mathematics, a right angle. Any figure resembling a plot, mathematics calls a rectangle. Why do we use this denomination? Should it be because it has tornos or vertexes? How many? Has it borders or sides? How many? Has it a right angle? How many? Are its sides parallel?

As can be observed, the students were asked to relate the mathematical conceptions of the horticulturists to those of formal mathematics, that is, to identify the characteristics of a rectangle: vertexes, angles and parallel sides in a local situation: the furrow representing a rectangle.

The second activity, relating to the vegetable garden and the notions of the area of geometric figures were composed of a text akin to questions, and said the following: vegetables need space inside the plots to grow, what in mathematics is called "area". To estimate the area necessary to the growing of each vegetable, horticulturists obey a span's distance to separate a vegetable from each other, as can be seen in Figure 10

(c) ETD-Educação Temática Digital $\quad$ Campinas, SP $\quad$ v.19 $\quad$ n.3 $\quad$ p.622-652 $\quad$ jul./set. 2017 


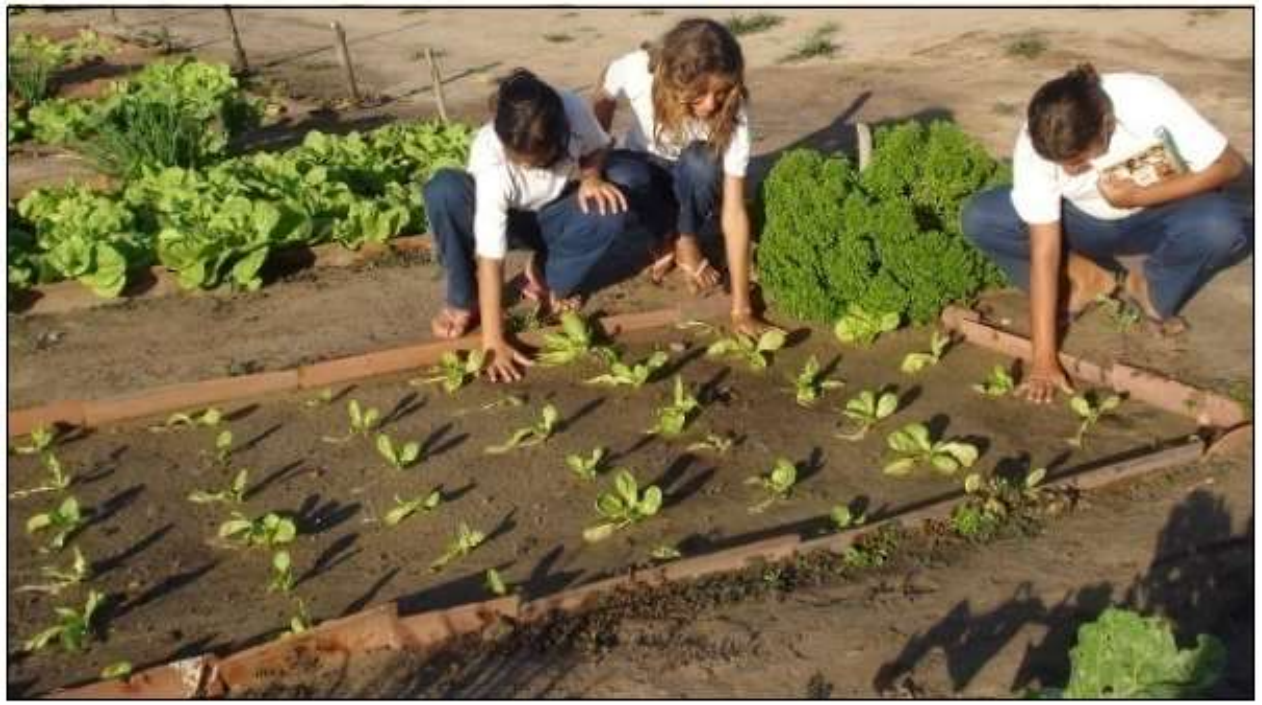

FIGURE $10-5^{\text {th }}$ graders of the local school in Gramorezinho are seen measuring, in spans, the spacing among the vegetables.

Source: Bandeira (2009)

Such a procedure amounts to square each furrow with small squares. As the vegetable garden is cultivated in the heart of each square, each plant has an area of a span by a span to grow, as can be seen in Figure 11, before-mentioned in Figure 8.

\begin{tabular}{|c|c|c|c|c|c|c|c|c|c|c|c|c|c|c|c|c|c|c|c|}
\hline$\bullet$ & $\bullet$ & $\bullet$ & $\bullet$ & $\bullet$ & $\bullet$ & $\bullet$ & $\bullet$ & $\bullet$ & $\bullet$ & $\bullet$ & $\bullet$ & $\bullet$ & $\bullet$ & $\bullet$ & $\bullet$ & $\bullet$ & $\bullet$ & $\bullet$ & $\bullet$ \\
\hline$\bullet$ & $\bullet$ & $\bullet$ & $\bullet$ & $\bullet$ & $\bullet$ & $\bullet$ & $\bullet$ & $\bullet$ & $\bullet$ & $\bullet$ & $\bullet$ & $\bullet$ & $\bullet$ & $\bullet$ & $\bullet$ & $\bullet$ & $\bullet$ & $\bullet$ & $\bullet$ \\
\hline$\bullet$ & $\bullet$ & $\bullet$ & $\bullet$ & $\bullet$ & $\bullet$ & $\bullet$ & $\bullet$ & $\bullet$ & $\bullet$ & $\bullet$ & $\bullet$ & $\bullet$ & $\bullet$ & $\bullet$ & $\bullet$ & $\bullet$ & $\bullet$ & $\bullet$ & $\bullet$ \\
\hline$\bullet$ & $\bullet$ & $\bullet$ & $\bullet$ & $\bullet$ & $\bullet$ & $\bullet$ & $\bullet$ & $\bullet$ & $\bullet$ & $\bullet$ & $\bullet$ & $\bullet$ & $\bullet$ & $\bullet$ & $\bullet$ & $\bullet$ & $\bullet$ & $\bullet$ & $\bullet$ \\
\hline$\bullet$ & $\bullet$ & $\bullet$ & $\bullet$ & $\bullet$ & $\bullet$ & $\bullet$ & $\bullet$ & $\bullet$ & $\bullet$ & $\bullet$ & $\bullet$ & $\bullet$ & $\bullet$ & $\bullet$ & $\bullet$ & $\bullet$ & $\bullet$ & $\bullet$ & $\bullet$ \\
\hline
\end{tabular}

FIGURE 11 - Representation of a plot from Gramorezinho. The dots represent lettuce seedlings and are separated from each other by a farmer's span.

Source: Bandeira (2009)

To be more exact, the geometric conceptions of the horticulturists appeared the moment they elaborated the plots and when they planted the vegetables calculating the spacing the seedlings needed. This spacing, in the case of the lettuce, means a span separating the seedlings. The procedure equals to square all the furrows with small squares. As the plant is placed not in the corners, but in center of the square, as Figure 8 shows, each little plant has a span-by-a-span area to develop. Thus, the area occupied by the seedling is preserved with the aid of linear measures.

After reading and discussing the text above, pupils were asked to answer the following questions:

(C) ETD- Educação Temática Digital $\quad$ Campinas, SP $\quad$ v.19 $\quad$ n.3 $\quad$ p.622-652 $\quad$ jul./set. 2017 
1) How many squares are there in the plot representation below?

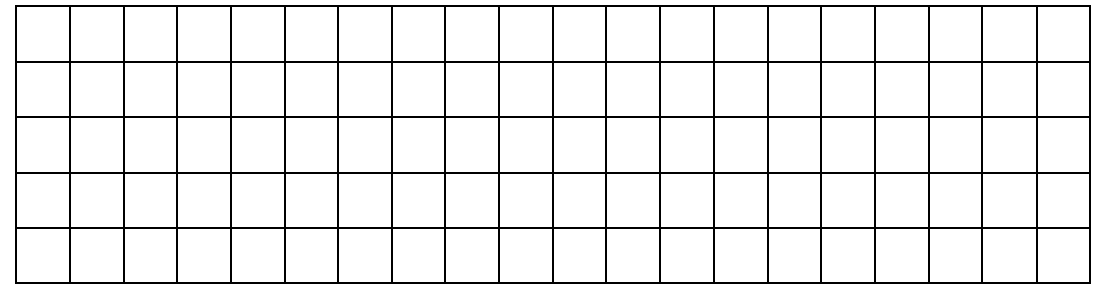

2) How many single lettuces can be planted at the representation above?

3) Does the number of vegetables amount to that of squares?

4) Which is the area in square numbers of the rectangle above?

5) In mathematics, if each small square had one-centimeter side, the space or area of each small square would have a square centimeter $\left(1 \mathrm{~cm}^{2}\right)$. Then, which would be the furrow area above?

Before these activities in the classroom, the pupils visited one of the vegetable gardens of the village, as can be seen in Figure 13. The objective of this field experience was to observe the rectangular format of the plots, the squared forms of the corners, the meanings of the borders and lathes that compose the furrow and seedbeds. Interviews with the horticulturists enriched the students' visit.

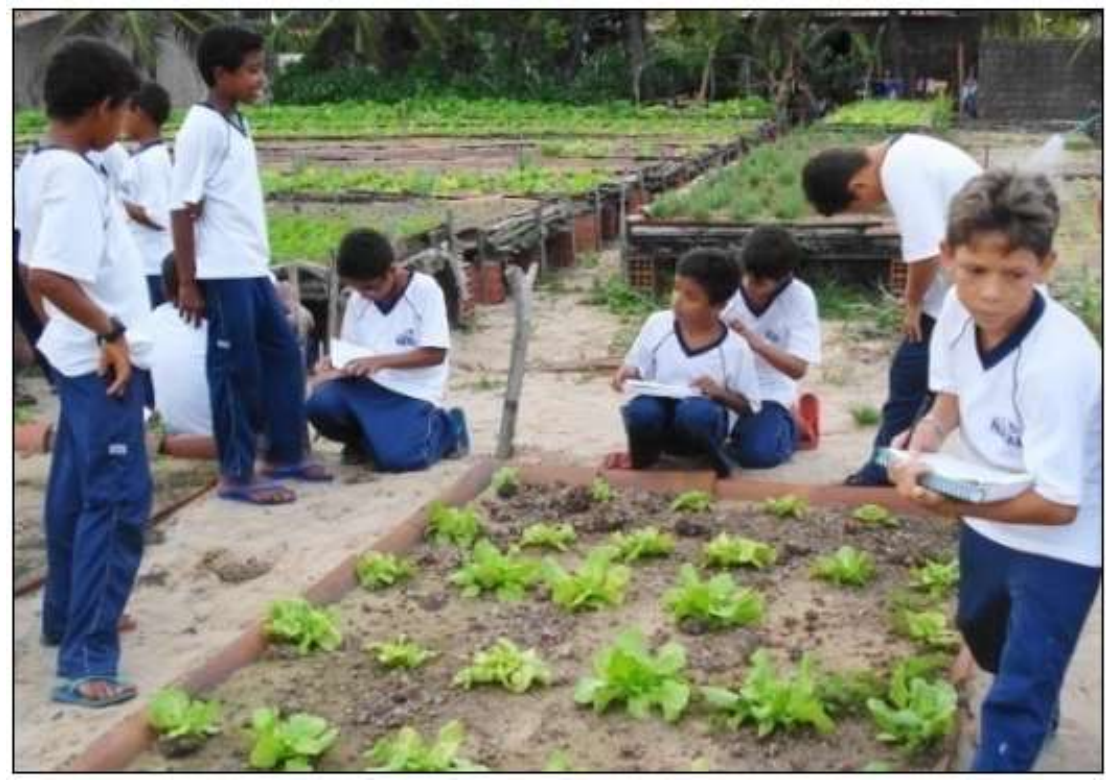

FIGURE $12-5^{\text {th }}$ graders pupils of the local school in research in Gramorezinho. Source: Bandeira (2009)

In fact, the visits to the village's vegetable gardens preceded the activities in the classroom, because the questions concerning that subject to be worked in class had to be elaborated previously. When a doubt was raised in the pedagogical process of studying, it 
was socialized with all the students and the teacher-researcher; and when it was not solved, could be tested by the horticulturists on the next visit.

\section{Greatness and Measures and Volume Measurement}

The learning dimension of Greatness and Measures is present in almost all activities held in the prevailing society, characterized by a strong social relevance and with obvious public and practical character. In this way, it plays an important role in the Mathematics curriculum of the school because it shows the utility of the mathematician knowledge in the daily life. It also intends to lead the 4th and 5th graders of the school to understand better the measuring methods and what aspects of this process are valid.

In addition, it aims at aiding learners to perceive the importance of choosing a certain "unit", comparing this unit with objects under measurement and counting the number of times that this unit was used. In this process, the students discover that, depending on the chosen unit, the measurement result can vary, and that there are units more adequate than others in function of what one wishes to measure. Although the learner can measure using non-conventional standards, it is important to know the conventional systems to enlarge his/her communication with today's society (BRASIL, 1997).

The conceptions of horticulturists in Gramorezinho in relation to volume measurement, length and time present examples of subjects that can be treated pedagogically in line with its learning dimension. Prior to this moment, however, it was necessary to analyze the ideas of the horticulturists in relation to volume measurements.

In the handling of volume measures, especially in the stages of manuring the vegetables and of manure commercialization, one of the mathematical revelations comes up in the village. In the realization of these activities a 18-liter tin can turns out to be the manure standard unit. The commercialization of manure in the village is held by the horticulturists using as local trade language the manure meter, that is, in the expression cubic meter they omitted the term cubic.

The owners of aviaries calculate the cubage of these inputs in line with the truck bucket experiences. Cubage is a typically algorithmic procedure used by small farmers in many northeastern states in Brazil, especially in relation to the practice of land surveying (land cubage). The term cubage is also used in the calculation process of wood logs (toras) (KNIJNIK, 2006). In the context of Gramorezinho, cubage is used to calculate the manure volume (BANDEIRA, 2002).

(C) ETD-Educação Temática Digital Campinas, SP $\quad$ v.19 $\quad$ n.3 $\quad$ p.622-652 jul./set. 2017 
When the manure bought in the aviaries arrives at the village, it is commercialized in bulk or in squared meter, and the relation between the cubic meter and the manure standard unit, that is, the 18-liter tin can, is of one to fifty. As the horticulturist explained: "I sell in [my standard unit is] the tin can, fifty cans are a meter. But, if the customer wants [to buy] in the bag, it depends on the bag".

The amount of manure necessary to the vegetable gardens (lettuce, coriander, spring onion and red pepper) and depends on the size of each plot. In a 2 meters $\times 20$ meters plot, the horticulturists use at most two fertilizations. Each one receives two 18-liter manure cans. The horticulturists use to say that if this proportionality manure/plot size is not respected, the vegetables can die, "burn", or the harvest is retarded.

In the fertilizing work of the vegetable gardens, besides using the 18-liter tin can, the horticulturists use also the wheelbarrow and an old wheat sack which accommodates respectively, three or four 18-liter tin cans in each. As what concerns the conception of cubic meters handled by horticulturists in their daily labor, one can infer that they possess the conception of volume, but express it their own ways.

Making a parallel between the volume measurements used by the horticulturists and the system of weights and measures of formal mathematics, it is known that a cubic meter amounts to 1000 liters. In the horticulturists' conception, a cubic meter of manure amounts to 50 tin cans, each one containing 18 liters. Transporting this volume conception to the formal mathematics, it sums 900 ( $50 \times 18$ liters). The 18-liter tin can used by the horticulturists is the same that is industrially manufactured containing oil, butter, ink or even kerosene, and is commercialized almost always sealed and with their contents below the full level.

The questions relative to the volume measures worked pedagogically with the pupils of the $5^{\text {th }}$ grade of the village and lead them to understand conventional conceptions of volume and capacity in line with the horticulturists' mathematical conceptions. In this regard, I elaborated problem situations with the horticulturists' mathematical conceptions with the aid of the mathematics textbook adopted by the school, but contextualizing it. In addition, the students visited one of the local vegetable gardens, as one can see in figure 13, where they interviewed a horticulturist that grew vegetables to sell in a free market.

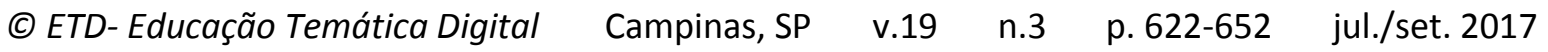




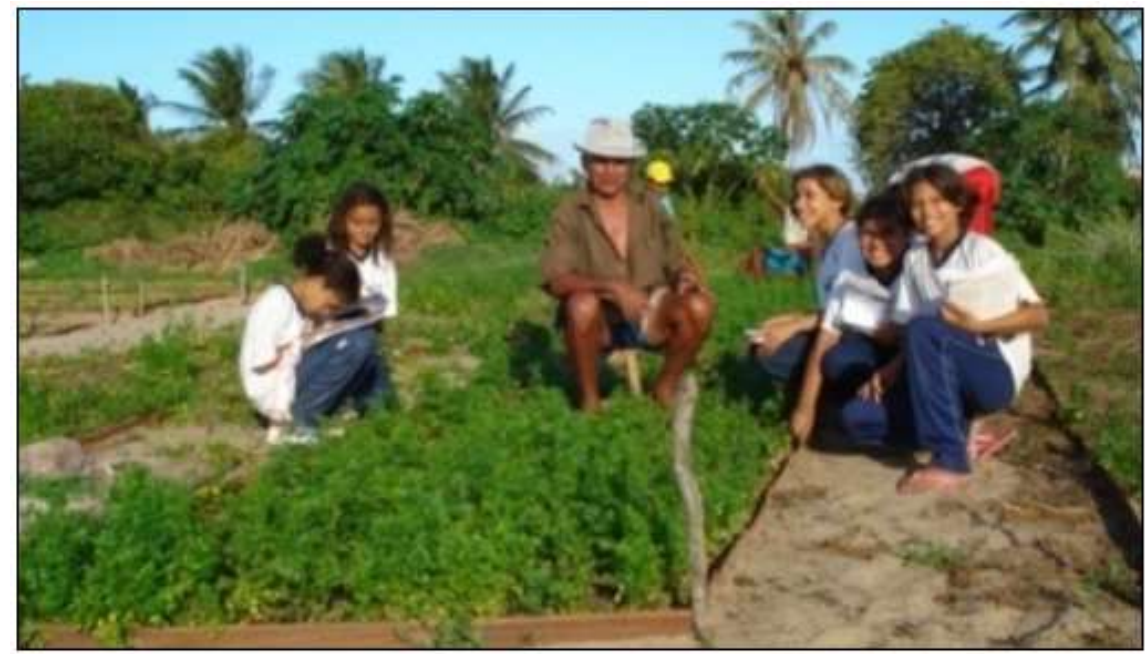

Figure $13-5^{\text {th }}$ grade pupils from Profa. Lourdes Godeiro Municipal School interviewing a horticulturist from Gramorezinho Source: Bandeira (2009)

The problem situation was the following: The amount of manure necessary for the vegetable gardens depends on the size of each plot. In a plot that is two meters wide and 20 meters long, a horticulturist will use three 18-liter cans of fertilizer. The manure meter in Gramorezinho corresponds to 18 liters. But it is known that the liter is the capacity unit, while the cubic meter $\left(\mathrm{m}^{3}\right)$ is the volume unit. Besides that, it is known that a cubic meter $\left(\mathrm{m}^{3}\right)$ contains 1000 liters.

After reading and discussing the text above, the pupils were asked to answer the following questions:

1) Which is the standardized capacity unit used today?

2) Which is the standardized volume unit used today?

3) How much is the capacity of the tin can used by horticulturists to measure the manure?

4) How many liters does a cubic meter contain?

5) How many liters of water do you drink in a day?

6) How many liters of water do you use in your bath?

7) How many liters of water does the water tank of your house contain?

8) A cubic meter amounts to 1000 liters. For Gramorezinho's horticulturists, a cubic meter of manure corresponds to 50 tin cans of 18 liters, that is, $50 \times 18$ liters = 900 liters. How many liters are lacking to a cubic meter in the language of the formal mathematics? 
Before starting this activity, I asked the pupils: how the vegetables were fertilized? Which materials the horticulturists utilized to measure the manure? A deeper analysis of these activities and other information concerning them are available in Bandeira (2016).

\section{CONCLUSIONS}

This work presents outlines related to three research works founded on Dambrosian conceptions of Ethnomathematics. The first work aimed at investigating the mathematical conceptions used by the potters from Currais Novos, in the process of manufacturing and commercialization of red tiles to support the elaboration of a pedagogical proposal in line with and connected to the formal mathematical knowledge of the village school. To achieve this goal, the researcher used as references the qualitative research in ethnographic approach and the Dambrosian conceptions of ethnomathematics.

After analyzing the data, this researcher identified the mathematical knowledge utilized by the potters, often different from those of the formal mathematics, in the following activities: in the method of counting tiles when loading a truck; when in buying raw-materials and commercializing tiles; in the tile's format, in the furnaces and in the tile sheds; in the calculation of the water volume that the potters used in the mix with clay; in the clay cubage during its purchase; in the cubage of the wood bought to feed the furnaces, and so on. However, because of space limitation, only two of these activities were pedagogically contextualized in detail.

The second work presented by $6^{\text {th }}$ grade school students coming from a village of workers from a red tile industry located in Russas, in the state of Ceará. The development and application process of educational intervention in this work sequenced four stages: 1 ) the research preparation; 2) Field research and data analysis; 3) Activity planning; and 4) Activity application. After the analysis of the educational process, the researcher observed that when the pupils act as the main agents of the process of data analysis coming from their own socio-cultural milieu, this situation contributes to the creation of a discussion space in class, while the students appear as critic subjects of their own reality.

The third research discussed here, was in relation to a curriculum reorientation in mathematics education by associating formal mathematics to the knowledge of horticulturists near Natal, in the state of Rio Grande do Norte. One of the results of this research showed the students that mathematics does not exist only in the classroom - that of the books, but everywhere, and that it is often different because cultures and contexts 
are different. In addition, mathematics awakened in interest in pupils who little by little, lost their fear of asking, of speaking of their doubts and difficulties.

The commercialization of manure in the village is held by the proper horticulturists using as local trade language the manure meter, that is, in the expression cubic meter they omit the term cubic. The owners of aviaries calculate the cubage of these inputs in line with the truck bucket capabilities. Cubage is a typical algorithmic procedure used by small farmers in many northeastern states in Brazil, along with the practice of land surveying (land cubage). The term cubage is also used in the calculation process of wood logs (toras) (KNIJNIK, 2006). In the context of Gramorezinho, cubage was used to calculate manure volume (BANDEIRA, 2002).

When the manure bought in the aviaries arrives at the village, it is commercialized in bulk or in squared meter, and the relation between the cubic meter and the manure standard unit, that is, the 18-liter tin can, is of one to fifty. As one horticulturist explained: "I sell in [my standard unit is] the tin can, fifty cans are a meter. But if the customer wants in the bag, it depends on the bag".

The amount of manure necessary for a vegetable garden depends on the size of each plot. In a 2 meters $x 20$ meters plot, the horticulturists used at most two fertilizations. Each one receives two 18-liter manure cans. The horticulturists used to say that if this proportionality manure/furrow's size is not respected, the vegetables die, "burn", or the harvest is retarded.

In the fertilizing work of the vegetable gardens besides using the 18-liter tin can, the horticulturists also used a wheelbarrow and a wheat sack which accommodated, respectively, three and four 18 -liter tin cans each one. As what concerns the conception of cubic meter handled by the horticulturists in their daily labor, one can infer that they possess the conception of volume, but express it their own unique way.

Making a parallel between the volume measurements used by the Gramorezinho horticulturists and the system of weights and measures of the formal mathematics, it is known that a cubic meter amounts to 1000 liters, in the formal mathematics. In the horticulturists' conception, a cubic meter of manure amounts to 50 tin cans, each one containing 18 liters. Transporting this volume conception to the formal Mathematics, it sums 900 ( $50 \times 18$ liters).

(C) ETD-Educação Temática Digital $\quad$ Campinas, SP $\quad$ v.19 $\quad$ n.3 $\quad$ p.622-652 jul./set. 2017 
The 18-liter tin can used by the horticulturists is the same that is industrially manufactured containing oil, butter, ink or even kerosene, and is commercialized almost always sealed and with their contents below the superior level.

\section{REFERENCES}

ARAÚJO JÚNIOR, Gilberto Cunha. A etnomatemática em uma cerâmica da região do SeridóRN. Dissertação de Mestrado. Natal, RN: Universidade Federal do Rio Grande do Norte, 2013.

ANDRÉ, Marli E. D. A. Etnografia da prática escolar. Campinas, SP: Papirus, 2000.

BANDEIRA, Francisco de Assis. A cultura de hortaliças e a cultura matemática em Gramorezinho: uma fertilidade sociocultural. Dissertação de Mestrado. Universidade Federal do Rio Grande do Norte. Natal, 2002.

BANDEIRA, Francisco de Assis. Pedagogia Etnomatemática: ações e reflexões em matemática do ensino fundamental com um grupo sociocultural específico. Tese de Doutorado. Natal, RN: Universidade Federal do Rio Grande do Norte, 2009.

BANDEIRA, Francisco de Assis. Pedagogia Etnomatemática: ações e reflexões em matemática do ensino fundamental. Natal, RN: EDUFRN, 2016.

BRASIL. Parâmetros curriculares nacionais: matemática. Brasília, DF: MEC/SEF, 1997.

D'AMBROSIO, Ubiratan. Etnomatemática: elo entre as tradições e a modernidade. Belo Horizonte, MG: Autêntica, 2001.

GERDES, Paulus. Cultura e o despertar do pensamento geométrico. Curitiba, PR: UFPR, 1991.

GOMES, Ana Lúcia Aragão. A dinâmica do pensamento geométrico: aprendendo a enxergar meias verdades e a construir novos significados. Tese de Doutorado em Educação Matemática. Natal, RN: Universidade Federal do Rio Grande do Norte, 1997.

GONÇALVES, Paulo Gonçalo Farias. A etnomatemática dos trabalhadores das cerâmicas de Russas-CE e o contexto escolar: delineando recomendações pedagógicas a partir de uma experiência educacional. Dissertação de Mestrado. Natal, RN: Universidade Federal do Rio Grande do Norte, 2013.

GRANDO, Neiva Inês. A matemática na agricultura e na escola. Dissertação de Mestrado em Psicologia. Recife, PE: Universidade Federal de Pernambuco, 1998. 
HOUAISS, Antônio. Dicionário Houaiss da Língua Portuguesa. Rio de Janeiro, RJ: Objetiva, 2009.

KNIJNIK, Gelsa. Educação matemática, culturas e conhecimentos na luta pela terra. Santa Cruz do Sul, RS: EDUNISC, 2006.

ROSA, Milton; OREY, Daniel C. Educação matemática: algumas considerações e desafios na perspectiva etnomatemática. Revista Educação Popular, v. 8, p. 55-63, 2009.

iThe grammatical and editorial revisions of this article were made by Daniel Clark Orey and Milton Rosa (UFOP). 